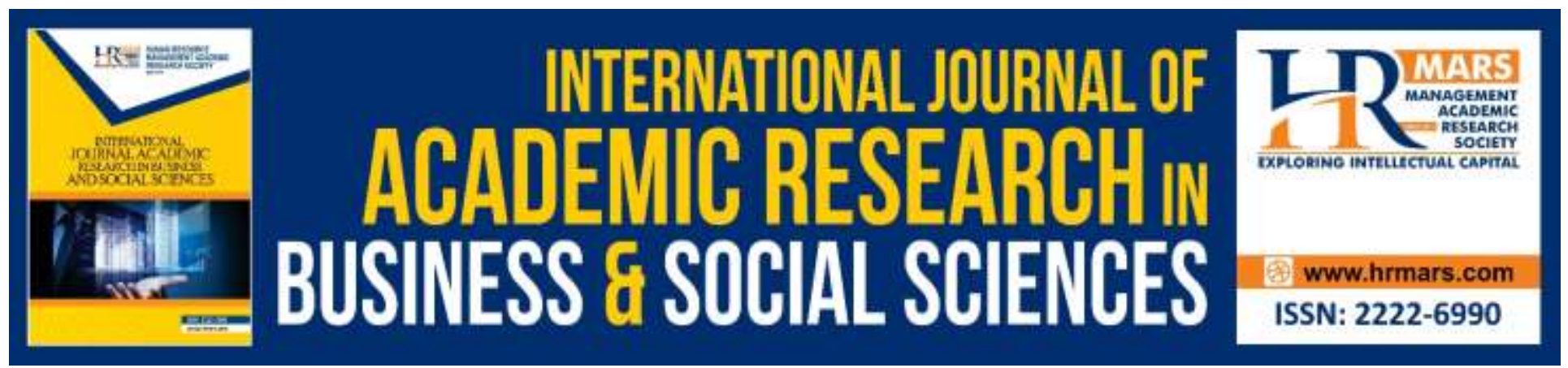

\title{
The Practice of Ta'dib Leadership among Islamic Education Teachers
}

Norhalimaton Saadiah Ayub, Mohd Isa Hamzah, Khadijah Abdul Razak

To Link this Article: http://dx.doi.org/10.6007/IJARBSS/v10-i3/7352

DOI:10.6007/IJARBSS/v10-i3/7352

Received: 26 January 2020, Revised: 28 February 2020, Accepted: 11 March 2020

Published Online: 29 March 2020

In-Text Citation: (Ayub et al., 2020)

To Cite this Article: Ayub, N. S., Hamzah, M. I., \& Razak, K. A. (2020). The Practice of Ta'dib Leadership among Islamic Education Teachers. International Journal of Academic Research in Business and Social Sciences, 10(3), 931-943.

Copyright: (C) 2020 The Author(s)

Published by Human Resource Management Academic Research Society (www.hrmars.com)

This article is published under the Creative Commons Attribution (CC BY 4.0) license. Anyone may reproduce, distribute, translate and create derivative works of this article (for both commercial and non-commercial purposes), subject to full attribution to the original publication and authors. The full terms of this license may be seen

at: http://creativecommons.org/licences/by/4.0/legalcode

\section{Vol. 10, No. 3, 2020, Pg. 931 - 943}

Full Terms \& Conditions of access and use can be found at http://hrmars.com/index.php/pages/detail/publication-ethics 


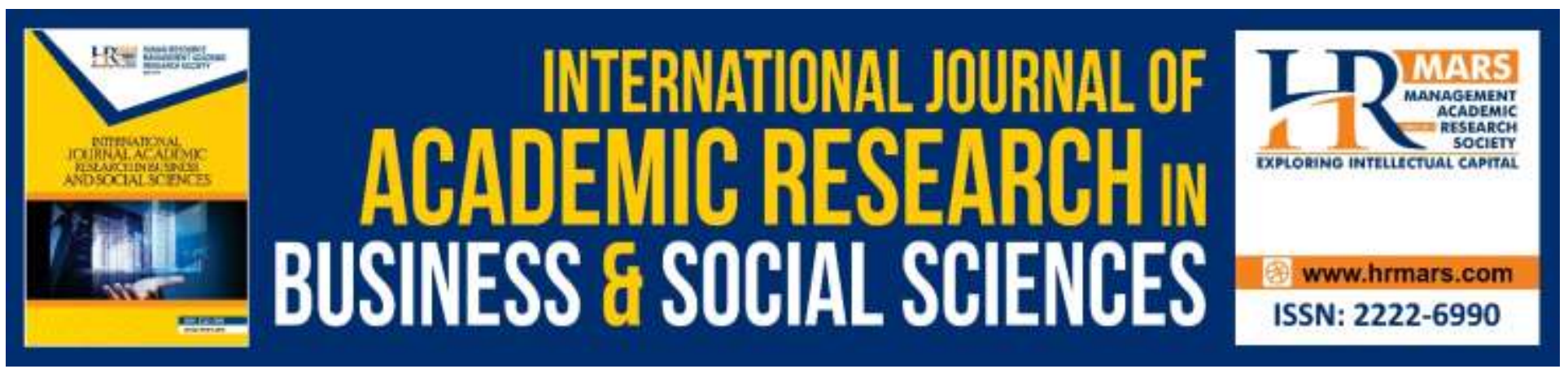

\title{
The Practice of Ta'dib Leadership among Islamic Education Teachers
}

\section{Norhalimaton Saadiah Ayub¹, Mohd Isa Hamzah², Khadijah Abdul Razak $^{3}$}

${ }^{1}$ Ph.D candidate, Faculty of Education, National Universitiy of Malaysia, ${ }^{2}$ Senior Lecturer, Faculty of Education, National Universitiy of Malaysia, ${ }^{3}$ Senior Lecturer, Faculty of Education, National Universitiy of Malaysia.

Email:norhalimaton99@gmail.com, isahamzah@ukm.edu.my,Khadijah.razak.@ukm.edu.my

\begin{abstract}
This article is based on a case study using qualitative approach which aims to explore the personalities of Islamic Education teachers as ta'dib leaders, subsequently discovering $t a^{\prime} d i b$ leadership practices by the Islamic Education teachers at schools. Data was collected using in-depth interviews and nonparticipant observation method involving seven participants of Islamic Education teachers from several schools using purposive sampling technique. The results of the data analysis found that Islamic Education teachers practise a superior personality traits as $t a^{\prime}$ dib leaders which centre around rabbani, trustworthiness, sincerity, charisma, patience and piety. These criteria complement the personality traits of Islamic Education teachers as the role models for the pupils at schools. Meanwhile, $t a^{\prime} d i b$ leadership practice is potrayed through spiritual nurturing, good examples, parental affection, supervisions and observations, advices and guidances, along with encouragements and rewards. Both elements concerning superior personality traits and effective leadership bring positive impacts towards the effectiveness of $t a^{\prime} d i b$ process in schools. This case study produces $T a^{\prime}$ dib Leadership Model which can be used as guidelines by all teachers in general and specifically the Islamic Education teachers in uplifting knowledge conveying processes and school education more proficiently.
\end{abstract}

Keywords: Islamic Education Teachers, Leadership, Ta'dib, Role Model.

\section{Introduction}

Teachers obviously play a prominent role in an education system. The education system may be great , but it will remain meaningless if the teachers who are supposed to be the role models are not into nurturing. In the Islamic context, a teacher does not only teach the students with knowledge, but also inculcate faith (Iman) and the students to be conscious and cognizant of God, of truth and always work in His obedience seeking His blessing (Taqwa). At the same time having luxuriate their souls with morals and good values. This means, Islamic Education does not only aim at achieving human excellence measured by intellectual values but also, upholding humans civilization values by placing 
INTERNATIONAL JOURNAL OF ACADEMIC RESEARCH IN BUSINESS AND SOCIAL SCIENCES Vol. 10, No. 3, March, 2020, E-ISSN: 2222-6990 @ 2020 HRMARS

morals as a precondition at the highest level and to a great extent. Educational practices in Islam sustain human development as highly educated and knowledgeable servants and caliphs of Allah; upholding noble intentions through their behaviours that enable them to think and behaving in accordance to Islamic rules to maintain peace on earth created by Allah. These noble goals are in line with the Messenger of Allah, Rasulullah SAW to guide human nations to achieve the perfection of values which in the end helps to spread goodness not only to Himself but also to other human beings around the whole universe (Ismail \& Jasmi, 2016). Due to that matter, the role of the Islamic Education Teachers is seen to be very prominent in making this education aspiration a reality, in addition, the responsibility to continue the Islamic legacy by the Prophets and Apostles of Allah now lies on their shoulders (Teh, 1986).

However, the adeptness of the Islamic Education teachers as the $t a^{\prime}$ dib leaders in schools is now beginning to be questioned. The rising rates of moral degradation among students are said to be correlated to the failures of certain Islamic Education teachers in displaying examplary morals, professionalism and Islamic conducts to the students (Ahmad \& Kassim, 2017; Jasmi, 2011) . A research by Mustafa et al (2012), said that there are Islamic Education teachers stigmatized by the students as being less responsible and do not represent the appropriate characteristics of the Islamic Education teachers. Meanwhile, a research by Hassan (2009) showed that $t a^{\prime} d i b$ leadership among Islamic Education teachers is till at the moderate level and needs to be improved. In this perspective, the same goes to a research by Suleiman (2014) which concluded that the Islamic Education teachers have not yet carried out effectively their roles as the moulder of morals especially in creating good rapport with the students at schools. All these issues must be overcome immediately in order to strengthen the credibility of Islamic Education teachers as $t a^{\prime}$ dib leaders.

\section{Concept of Ta'dib}

The term of $t a^{\prime}$ 'dib is taken from 'addaba' which means to educate and the teaching of morals (Suhid, 2006). The use of the term $t a^{\prime} d i b$ is recommended to potray the whole essence of Syumul or perfection. Islamic Education is supported by faith (Iman) values along with the conciousness and cognizance of God (Taqwa) braced by the sublime manners in Islam (Al- Ghazali , 1993; Al- Attas, 2018; Ahmad, 2017). This view is based on hadith Ibn Hibban in which Rasulullah SAW said;

"The Lord has edified me, therefore He has bestowed me the best of education"

Al-Attas (2018) has referred manners to discipline, spiritual, thoughts, feelings and actions which enable a person to identify and emplace certain matter to its rightful position, in which it already determines the revelation of Allah (Pa, 2014). Reflecting on that matter, Othman (2014) said that $t a^{\prime} d i b$ has very much to do with the concept of knowledge in Islam which is the enlightment that has a purpose to inculcate good values in human beings in developing noble and good individuality. Therefore, it will help to build awareness and conciousness of responsibilities that bring bliss in this worldly life and Hereafter. Moreover, putting efforts to sincerely execute such responsibilities based on the settings of morality and religious requirements. Conclusively, the real $t a^{\prime} d i b$ is an education system which stresses on the concept of faith (Iman), knowledge and practices as the whole (Mohamad \& Razak, 2016).

Essentially, the connotation of $t a^{\prime} d i b$ itself symbolises a comprehensive education system pertaining the process of $t a^{\prime} l i m$ and tarbiyah which emphasizes the developing of individuals with good morals and balanced whole beings (kamil) in general as one of the educational goals (Daud, 2005) meant not only as loyal servants and caliphs of Allah who possess great spiritual dimension, in which obedient and submissive only to Allah, whereas the outer dimension is able to bring security 
INTERNATIONAL JOURNAL OF ACADEMIC RESEARCH IN BUSINESS AND SOCIAL SCIENCES Vol. 10, No. 3, March, 2020, E-ISSN: 2222-6990 @ 2020 HRMARS

in the social circle (Hamzah, Ibrahim, Ismail \& Zuki, 2013). Primarily, this concept is the basic development and morality growth which is perfect enough to produce a unified and definite human resource in achieving joy in this worldly life and Hereafter (Hamat \& Nordin, 2012; Nugraha, 2017). In the context of Islamic Education execution in Malaysia, ta'dib refers to a process of building, expanding and enhancing manners and Islamic morality in an individual. It is to uphold the human resource which consists of spiritual values and high ethics as a result of spiritual, emotional, physical and intellectual consolidation relevant to the aims and aspirations of Malaysia Education Blueprint 2013-2025.

\section{Islamic Education Teachers as Leaders}

Reflecting back on the education aims in the Islamic Education Philosphy, it clearly potrays that the task being carried out by a teacher in producing kamil individuals is a serious matter. Therefore, this education aims have to be supported by those educators who are really into commissioning the roles of educators community (murabbi) and holding it as a will from Allah that has to be implemented the best way there is.

In this connection, teachers have to see that they are the leaders who know, understand, aware and willing to execute the duty to lead profoundly in awareness and appreciation. A teacher has to feel it in himself the urge to see the students he guides to become individuals who will be true believers, noble and capable of contributing felicity not only to themselves, but also to their families, society and the country in general (Ahmad \& Kassim, 2017). Consequently, as the teachers and leaders at schools, Islamic Education Teachers must inculcate, edify, guide and instill good manners and implant good morals in the students' lives (Jasmi \& Tamuri, 2007). The executions of effective $t a^{\prime} d i b$ requires the leadership from adept teachers in order to implement their roles and guidance, educators and the ones who inculcate Islamic values in the students' souls, in which persuading them to be good examples and the best examplary (qudwah) in all aspects (Ramlie \& Hussin, 2017; Mokhtar, 2017).

In this matter, verse 24 and 25 Surah Ibrahim can be a guideline to elaborate the characteristics of a teacher as the good leader. These verses describe the characteristics of a real Muslim and should be practised by an individual we call a teacher or an educator, Allah s.w.t said ;

" Have you not considered how Allah sets forth a parable of a good word (being) like a good tree, whose root is firm and whose branches are in heaven. Yielding its fruit in every season by the permisssion of its Lord? And Allah sets forth parables for men that they may be mindful."

(Basmeih , 2010)

In those verses, Allah has made an analogy that a good Muslim or a teacher is like a strong tree. The roots reach deep into the earth which is like the faith (Iman), and this faith (Iman) is fertilized with knowledge till the tree bears tremendous branches and stems. The growing branches and stems are similar to the religious practices and Islamic appreciation. The perfect tree will yield sweet fruits comparable to the good morals. These morals are categorised as true Iman to Allah (al Zuhayli, 2007). Meanwhile, the prominent value of Iman is related to being sincere as the visualisation of the quality of faith (Iman) a person possesses. Without the element of sincerity, other elements such as faithfulness, practices, appreciation and morality will be useless in the eyes of Allah because it does not come from the willingness and awareness in carrying out all matters and duties (Fakhruddin, 2012). 
INTERNATIONAL JOURNAL OF ACADEMIC RESEARCH IN BUSINESS AND SOCIAL SCIENCES

Vol. 10, No. 3, March, 2020, E-ISSN: 2222-6990 @ 2020 HRMARS

This matter describes the fact that a teacher has to own good and noble qualities in himself based on his faith (iman) to Allah to enable himself to rise as a good and adept guidance and leader for the students. He must always be someone who consistently potrays a high standard of morality mirrored in the way he speaks, his words, actions, manners and his appearances. These qualities can be observed by the students without hesitations (Tamuri, \& Ajuhary, 2010). In this perspective, the adeptness of a Muslim teacher or educator in the efforts to execute the duties of educating and leading the students will be more effective by transforming themselves into qudwah hasanah or the role models to the students (Tamuri \& Jasmi, 2007).

\section{Research Objectives and Research Questions}

This research was done to explore the characteristics of Islamic Education Teachers as leaders and how these $t a^{\prime}$ dib leadership practices are being carried out by these teachers at schools. This research findings would be answering two research questions which centred around: (1) What are the characteristics of the Islamic Education teachers meant as ta'dib leaders? (2) How are ta'dib leadership practices being implemented at schools?

\section{Research Methodology}

In order to find the answers to these questions, qualitative research method was used to collect detailed information relevant to a certain phenomena in a real situation as suggested by Cresswell \& Poth (2018). The research finding would be answering the questions of what are the characteristics of Islamic Education Teachers as $t a^{\prime}$ dib leaders and how are these practices being implemented at schools. The form of this research was a case study or precisely known as multisite cases due to the several school locations believed to be more reliable for the data to be collected (Merriam \& Tisdell, 2016). This case study inlvolved seven Islamic Education Teachers as the primary research respondents chosen through purposive sampling to suit the characteristics set by the researcher ; one of those is the teachers should at least have eight years of teaching experiences and of DG 48 and above, degree in Bachelor of Education or Diploma in Education holders. Moreover, the respondents must be amiable, approachable and willing to share information.

The data collected through these in-depth interviews involved seven Islamic Education Teachers, seven colleques, seven administrators and fourteen students including observations. The data was analysed inductively, beginning with an open documentation using constant comparative technique until the process to design the categories and themes are conducted (Merriam \& Tisdell, 2016; Othman, 2017). To increase the research validity and realibility, the researcher has done triangulation method, peer review, members check, remaining at the research field validation through three chosen experts to do counter checks and subsequently validate the theme being constructed by the researcher where cohen kappa value identified is 0.92 , indicating that this research data are highly reliable.

The data used in this article were coded as [IV/IET2] and (S) or (C): IV (interview), IET (Islamic Education Teacher), 2 (Number of participant) and (S) stands for student and (C) for colleague.

\section{Findings}

Data analysis findings were obtained through in-depth interviews and unparticipating observations method, the researcher constructed the main themes to answer two research questions. For the first question to ponder regarding the Islamic Education Teachers as $t a^{\prime} d i b$ leaders, the researcher has 
INTERNATIONAL JOURNAL OF ACADEMIC RESEARCH IN BUSINESS AND SOCIAL SCIENCES Vol. 10, No. 3, March, 2020, E-ISSN: 2222-6990 @ 2020 HRMARS

identified six main traits concerning divinity (rabbani), trustworthiness, sincerity, adeptness, patience and piety.

Islamic Education Teachers have the characteristics of being rabbani leaders who firmly upholding the principles of divinity by ensuring that every action and behaviour is polarised based on faith towards Allah. As taqwa leaders, Islamic Education Teachers are always seeking the truth, passionate towards knowledge, practising Islamics teachings, staying firm with the noble morality and preventing deeds that can lead to sins and are unnecessary; as a matter of fact having a strong urge to guide the students towards goodness and seeking Allah's favor. Therefore, the students' morals growth or development should be a priority because a person with good morals but lack of knowledge is better than a learned one without commendable morality.

" A student helping us sincerely is something we cannot compare to money. The letter ' $A$ ' is only a grade written on a piece of paper, anyone can achieve it. But, a student's morality, religious practices, being respectful to the teachers, those are the right deeds that cannot be put into the value money can give.Those are more valuable than money itself, than the grade we put on paper as well" [IV/IET5]

The second trait of a ta'dib leader is trustworthiness which is to perform duties as an educator and responsibilities to educate the students the best ways there are, to achieve the goals in education in order to produce knowledgeable and well-mannered students. As the responsible leaders, the Islamic Education teachers always put the students' welfare before themselves. This is described by the student being interviewed .

"When she teaches, she is very earnest.She teaches with all her heart. She makes sure we will understand what she is trying to tell us.After lessons, she'll make sure we'll do the exercise" [IV (S)/ IET3]

The next characteristics are sincerity and adeptness. Sincerity comes from the character of ' $a$ lAmin', the realization that the role of an educator is a responsibility or a commend from Allah which will be asked on the Day of Judgment. Therefore, the Islamic Education Teachers carry out the duty based on some sets of rules and procedures, hoping for Allah's favor while not expecting any rewards and appreciation from humans. They take their duties as a way of worshipping Allah and a platform to do good, 'As a teacher, sincerity is a must, not just worldly, to get paid monthly. This way, it becomes an act of worshipping, an ibadah. Thus, [you] will get the reward' [IVIET1, 2018]. The sincerity in working will produce teachers who are committed, efficient and willing to sacrifice for the sake of their students. These said characteristics make their adeptness and skills stand out in the eyes of their students making them being respected and trusted as leaders in the religious and spiritual activities. Their words act as guidance and their actions are being followed. Their presence in school is anticipated. This is acknowledged by a fellow Islamic Education Teachers' colleague; "She has the spirit, she seems to have the aura. How to say ... her leadership aura ... then, she is good in disciplining the students. When students see her, they will automatically be disciplined and they obey her. Like you can't joke around" [IV (C)/ IET2]

Besides, patience and saying a prayer are other characteristics of Islamic Education Teachers. As a leader to students who come from various backgrounds and behaviours, being patient is crucial. Patience makes a Islamic Education Teachers always persevere, have an open heart, positive and constantly educating students without giving up, 'Most importantly, we must not give up, always persevere (istiqamah). Do not feel tired to correct and remind them of the good deeds' [IVIET5, 2018]. 
INTERNATIONAL JOURNAL OF ACADEMIC RESEARCH IN BUSINESS AND SOCIAL SCIENCES Vol. 10, No. 3, March, 2020, E-ISSN: 2222-6990 @ 2020 HRMARS

They are also loved by the students because of the patience shown while teaching. The soft and wise approach is more favored and used by the Islamic Education Teachers s and they are not in a hurry to reprimand the students.

"He is a soft-spoken person. Teenagers nowadays do not like it when a teacher is always scolding. So, this ustaz actually hardly gets angry. He will advise a student gently" [IV (S)/ IET7]

While praying complements all the hard work shown by the Islamic Education teachers, it is also the ultimate act derived from the patience and determination, hoping to receive Allah's guidance to give a good consequence. In this case, the Islamic Education teachers are always praying for the students, hoping they will be guided to be a better person and one with good morals. The Religious Education teachers are assured that with hard work and sincere prayers, the task of educating students will be eased.

"We pray for the student. Do not let him go. Which means, if there is still time, call him. Advise him so that in the end his heart will soften" [IV/IET1]

To answer the second research question that is how do the Islamic Education Teachers carry out the $t a^{\prime} d i b$ leadership practice in school, the researcher identified six ta'dib leadership practices applied by the Islamic Education Teachers, that is through the spiritual approach, through exemplary, showing parental affection, supervision and observation, through advice, as well as encouragement.

The Islamic Education Teachers apply the $t a^{\prime} d i b$ leadership practice through the spiritual approach by showing a high level of religious appreciation as well as making Islam as the way of life. The Religious Education teachers are always aware of their obligatory prayers, performing the sunat prayers, keeping the boundaries when socializing, and staying away from unbeneficial things. Therefore, the Islamic Education Teachers are known as someone who is good, pious and humble (tawadhuk). These characteristics not only lead them to become good servants of Allah, but they also help them to lead students to become good people. The Islamic Education Teachers are always concerned of the students' religious practices by reminding them of their obligatory prayers, covering their aurah and reciting the Al-Quran. Islamic Education Teachers are constantly trying to instill the seeds of faith and piety within the students through practices like supplicating, reciting the zikr and the Al-Quran;

"That's how to soften their hearts and ways for them to obey us. Include the words of Allah, then it would be easy. Who knows how long they haven't prayed, they do not submit to Allah's orders, let alone ours" [IV/IET2]

This is admitted by a student interviewed :

"Normally, ustazah will remind us to always take care of our relationship with our parents, our relationship with Allah. Ustazah said for us to maintain our relationship with Allah, we have to perform our prayers (solat). Be aware of our solat. Ustazah said praying is important. After that, have a good relationship with the Al-Quran by reciting it always" [IV (S)/ IET6]

The second $t a^{\prime}$ dib leadership practice is through good exemplary to students. The Islamic Education Teachers believe that a teacher is a role model to students. Their every word and action 
become the center of attention to the students. Therefore, a teacher has to be aware of their actions and be careful in taking actions so that their credibility and adeptness will not be affected. They show good examples through good behaviour practices such as politeness, soft-spoken, respectful, loving and ready to assist. These noble characteristics should be instilled in a teacher because as a leader, displaying a good exemplary has a huge impact on students. A teacher who successfully shows good examples and one who always practices the knowledge implied will be more respected and trusted by students;

"To me it is 'uswatun hasanah'. To me how strong 'uswah hasanah' is. Sometimes, we don't have to talk about something but our morals will show. We don't always have to repeat you have to do this, you have to do that but through uswatun hasanah, students will see, students will observe" [IV/IET7]

A student interviewed also admitted that the Islamic Education teachers always show a high moral of Islam in every aspect making them being looked up to and respected by anyone. Eventhough as a leader they can demand the students' respect, the Islamic Education teachers remain humble and portrays a loving attitude and respectful of students.

"If a student bumped into him, he would give greetings. If the student is a Muslim, he would give greetings in Arabic, if it is a non-Muslim, Ustaz would put up his hand in acknowledgement. I have seen Ustaz giving the greetings first" [IV (S)/ IET5]

On top of that, the Islamic Education Teachers apply the $t a^{\prime} d i b$ leadership practices by portraying parental affection. A teacher takes over the role as a family leader to educate, advice and guide students to do good in school. Thus, a teacher treats the student as their own child. Islamic Education teachers are friendly, approachable, has an open heart and patient in entertaining students' various behaviours. The teachers show that they are caring, aware and concerned of the students' welfare and tries to lift their burden and difficulties. This way, students would feel loved and appreciated. They will always be excited and motivated to go to school because there is a teacher who would always give them the utmost attention and love alongside imparting the knowledge needed.

"But if we do that by taking care of their welfare. Make them closer to us. And he will be eager to come to school because he knows there is a person who cares for them in school. So, he is happy to be in school even though he might be in a difficult situation" [IV/IET5]

From a different aspect, $t a^{\prime}$ dib leadership practices by the Islamic Education teachers are shown through supervisions and observations. The Islamic Education Teachers constantly supervise and observes the students' behaviour from time to time. He acknowledges and cares for the students' development and always ask about their prayers, their academic achievements and their attitude problems, by conducting discussions with colleagues to find the best solution to overcome the issue including paying a visit to the problematic student's house. The teachers never leave the students astray, in fact they show a degree of openness and toleration to understand the students' condition. The Islamic Education teachers' way of supervising is explained as below;

"If the student is moving, we can see him from afar that he is not motivated. Walking so weak. So we might ask, 'why are you late today? To which he answers, 'The teacher let us 
INTERNATIONAL JOURNAL OF ACADEMIC RESEARCH IN BUSINESS AND SOCIAL SCIENCES Vol. 10, No. 3, March, 2020, E-ISSN: 2222-6990 @ 2020 HRMARS

out late'. 'I see you walking form here and I know that you're not motivated'. So, we have to pull him back. 'Why, didn't you eat? Haven't you performed your Subuh prayer?" [IV/IET6]

Next, the Islamic Education teachers display ta'dib leadership practices by giving good advice to the students. Showing good exemplary is not enough to carry out a good leadership task. Although students can observe and mimic good behaviours, they still need to be advised and corrected due to their negative surrounding. Realising this, as a leader, the Islamic Education teachers are never tired in giving advices and reminders to students so that they will remain steadfast in obeying Allah and staying away from committing any wrongdoings. These advices and reminders are delivered with full wisdom, sincerity and not putting the students to shame.

"We cannot get tired of advising. Cannot be tired of doing so. Well, have been saying that for so many times, advise. Dozens of times already. But that is what education is all about. We have to advice even though a thousand times. Do not get tired" [IV/IET3]

To strengthen the $t a^{\prime} d i b$ leadership practices in school, the Islamic Education teachers apply this practice by giving encouragement and rewards to students. They are generous in giving encouragement in the form of positive words, compliments, pats, smiles, claps and also presents for students' achievements. With this, the Islamic Education teachers are successful in leading and managing the classroom well and are able to create a conducive learning environment that is filled with love, intimacy and appreciation. This environment was recognized by the researcher during the classroom observations. For example, the teaching process handled by one of the Islamic Education Teachers. The students really enjoyed themselves, they were happy and gave their full attention and cooperation to the teacher. Islamic Education teachers involved was always cheerful, smiling and patient in entertaining the students. She was not angry when answers given were incorrect, instead she smiled and said "It's okay, Amira. Try again". She was always open, accepted the students as they are and appreciated as well as celebrated their work by saying, "Wowww! Amazing! Good!", all the while smiling and showed a thumbs up sign to her students.

\section{Discussion and Conclusion}

Based on the research results, it is evident that the Religious Education teachers have the personal characteristics as a good leader like rabbani (knowledgeable of God), sincere, trustworthy, authoritative and saying prayer. The results reinforce previous researches by Mokhtar (2017), Mohamed et al (2016), Jaafar \& Rashed (2015), Suleiman (2014) and Jasmi (2010). The characteristic of rabbani which is centered on the value of a higher being like faith and taqwa is the key that shapes the superior personality of the Islamic Education Teachers that enables them to perform their role as a respected $t a^{\prime}$ dib leader in school. Their characteristics and actions mirror a high level of faith and provide a positive influence to the students as the people whom they are guiding (Fakhruddin, 2015). Next, this characteristic becomes the factor in encouraging the Islamic Education teachers to apply effective leadership practices towards achieving the goal of $t a^{\prime} d i b$ that is to shape a whole (kamil) human being. The teachers' leadership practices based on the spiritual aspect can help instill the value of faith among students. The study results also strengthen the recommendations by renown Islamic scholars like al-Ghazali (1993), Nashih (1989) and al-Attas (2018) for teachers to appreciate their faith and religious life because this gives spirit and soul in shaping students' moral. A teacher who possesses a high level of spirituality is able to inculcate godly soul within students until they are pushed to do good and leave the bad as they realise that everything is in the knowledge of Allah. 
Essentially, students will receive the blessings of the knowledge and they will become a good person with good values everytime and everywhere (Hamzah et al, 2014)

At the same time, the Islamic Education teachers make their appearance, attitude and personality as good examples (qudwah) that would portray the beauty of the Islamic morality like patience, sincerity, trustworthy and loving to their students. Possessing a high morality is the best weapon for a leader to influence the students to do good. This finding reinforces the research done by Salleh, Ahmad, Noh \& Hehsan (2018) which shows that Islamic Education teachers who apply the qudwah strategy in the eyes of the students include their actions, words, and their appearance. A teacher with high morality shows adeptness and credibility as a leader in carrying out the duty and responsibility entrusted very well. This finding not only in line with existing researches but reinforce them in that the personality aspect of a teacher as a role model can be a platform in shaping good values in students, such as the research of Hussin (2005) and Tamuri \& Ajuhary (2010), with the practice of parental love like being friendly, loving, concerned and caring of students' problems which is synonymous to the leadership qualities of the Islamic Education Teachers in schools. This finding is also parallel with the study conducted by Mohamad \& Sahad (2014) and Mokhtar (2017) which proves that Islamic Education Teachers always practice the best practices to preserve their duty and responsibilities in school.

For the next leadership practices, that is supervision and observation of students' behavior, it is the teachers' duty to give advice and correct students in the best way possible apart from giving encouragement. This is a leader's role that cannot be separated from teachers. In educating, supervision, advice and encouragement are elements that could strengthen the process of building and shaping the students' behavior and morals. This result is in line with the view of Jasmi \& Nawawi (2012) which put these three characteristics as among the most effective personalities of Islamic Education Teachers. Students cannot be let to wander without guidance and guidelines alongside having the need for continuous reinforcement for them to act good and be polite. These three things, if implemented successfully by the Islamic Education teachers, will finally shape a good habit and routine in the students to the extent that they can act in line with the religious and Islamic will (Tamuri, \& Ajuhary, 2010) and at the same time increasing their interest and motivation towards Islamic Education (Jasmi et al, 2009).

Thus, based on the study results, the $t^{\prime}$ 'dib leadership model is suggested as a guideline for Islamic Education teachers specifically, and to all teachers generally to become an effective educator and leader in schools. This model includes two main elements which are the characteristics and personality of a $t a^{\prime} d i b$ leader and the leadership practices that are able to generate committed hard work in realizing the aim of producing a whole individual who has strong faith, knowledgeable and has good morals. The ta'dib leadership model is depicted in the diagram 1 below; 


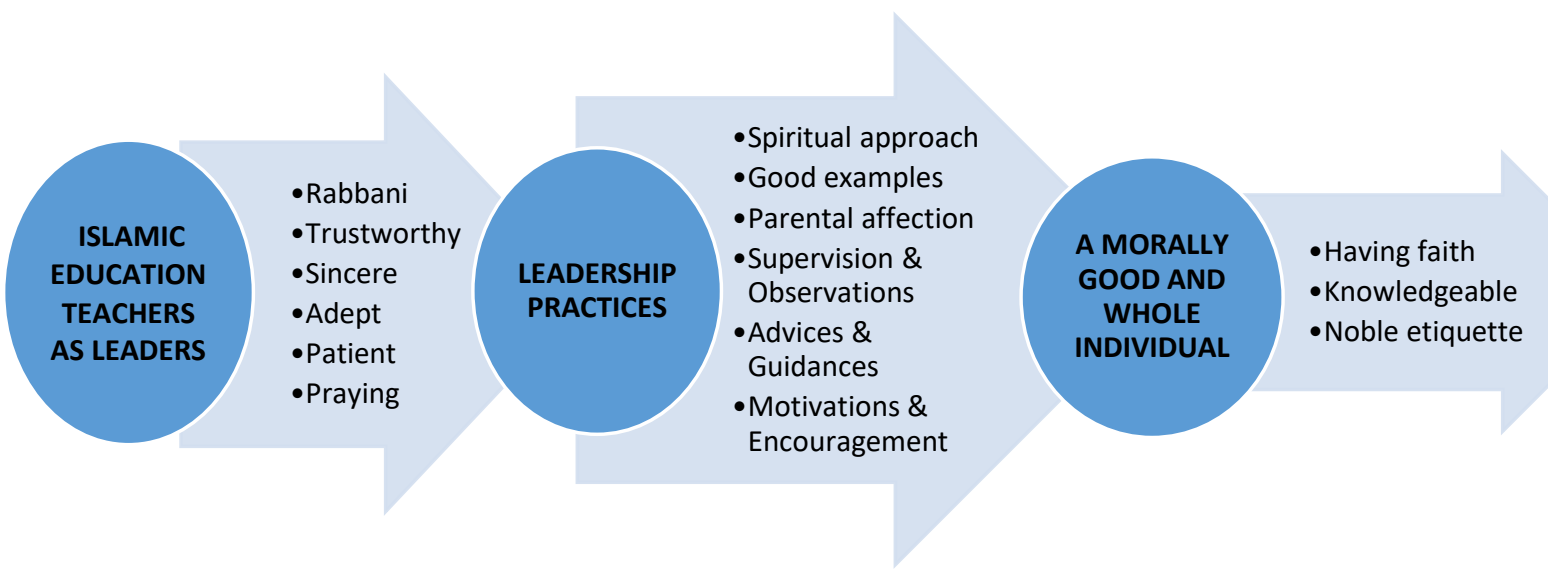

INPUT

PROCESS

OUTPUT

1: Islamic Education Teachers Ta'dib Leadership Model

Diagram

In conclusion, the Islamic Education Teachers as a model have to constantly equip themselves with the values of faith and a high level of spirituality, have a sound knowledge and a noble personality because they are models who will be looked up to and followed by the students in school.

\section{Acknowledgement}

I would like to express my heartfelt gratitude to Dr Mohd Isa Hamzah of National University of Malaysia for his suggestions and guidances in the writing of this manuscript. I would also like to thank the Ministry of Education of Malaysia for the financial assistance. This research could not have been completed without their support.

\section{Corresponding Author}

Norhalimaton Saadiah Ayub

Ph.D candidate, Faculty of Education, National Universitiy of Malaysia.

norhalimaton99@gmail.com

\section{References}

\section{Al-Quran}

Ahmad, K. (2017). Principle of Islamic Education. Kajang: Kolej Dar al-Hikmah.

Ahmad, S. S., \& Kasim, T. S. A. T. (2017). Problems and challenges of Islamic studies teachers in shaping students' personality and morality: A critical analysis. In Proceedings of the International Conference on Islam, Development and Social Harmony in Southeast Asia, (Vol. 238, pp. 1-15).

Ahmad, S. S., \& Kasim, T. S. A. T. (2017). The role of Islamic education teachers in the development of student personality: A preliminary survey of Islamic education teachers in Marang district, Terengganu. Journal of Islamic Educational Research, 2(2), 36-53.

Al-Attas, M. N. (2018). The concept of education in Islam. Kuala Lumpur: Ta'dib International Sdn Bhd. 
INTERNATIONAL JOURNAL OF ACADEMIC RESEARCH IN BUSINESS AND SOCIAL SCIENCES

Vol. 10, No. 3, March, 2020, E-ISSN: 2222-6990 @ 2020 HRMARS

Al-Ghazali. (1993). Bimbingan Mukmin. Singapura: Pustaka Nasional Pte Ltd.

Al-Zuhayli, W. (2007). Al-tafsir al-Munir fi al-aqidah wa al-syari'ah wa al-minhaj. Damsyik: Dar alFikir.

Creswell, J. W., \& Poth, N. C. (2018). Qualitative inquiry \& research design: Choosing among five approaches. Los Angeles: Sage Publications.

Daud, M. N. W. (2005). Falsafah dan amalan pendidikan Islam Syed M. Naquib al-Attas: Satu huraian konsep asli Islamisasi. Kuala Lumpur: Penerbit Universiti Malaya.

Fakhruddin, F. (2012). Peranan dan cabaran guru pendidikan Islam. Serdang: Universiti Putra Malaysia.

Hamat, M. F., \& Nordin, M. K. N. C. (2012). Akidah dan pembangunan modal insan. Kuala Lumpur: Penerbit Universiti Malaya.

Hamzah, R., Ibrahim, T. N. T., Ismail, S., \& Zuki, R. E. A. (2013). Pembangunan jiwa pendidik dalam kalangan bakal pendidik. Jurnal Teknologi, 61(1), 27-31.

Hussin, Z. (2005). Mendidik generasi berakhlak mulia: Fokus peranan guru Pendidikan Islam. Masalah Pendidikan, 28, 79-94.

Jaafar, N., \& Rashed, Z. N. (2015). Model kualiti guru pendidikan Islam sebagai murabbi. Tinta Artikulasi Membina Ummah, 1, 101-108.

Jasmi, K. A. (2010). Guru cemerlang pendidikan Islam sekolah menengah di Malaysia: satu kajian kes. Doctoral dissertation, National University of Malaysia.

Jasmi, K. A., \& Nawawi, N. F. (2012). Ciri guru pendidikan Islam berkesan. In Seminar Antarabangsa Perguruan dan Pendidikan Islam[SEAPPI2012] (pp. 1-8). Senai, Johor. Retrieved from http://eprints. utm. my/36629/1/Cover\% 2526Paper. pdf.

Jasmi, K. A., \& Tamuri, A. H. (2007). Pendidikan Islam: kaedah pengajaran \& pembelajaran. Johor Bahru: Penerbit UTM Press.

Jasmi, K. A., Tamuri, A. H., \& Hamzah, M. I. M. (2009). Sifat dan peranan keperibadian guru cemerlang pendidikan Islam (GCPI) dan hubungannya dengan motivasi pelajar. Sains Humanika, 51(1), 57-71.

Merriam, S. B., \& Tisdell, E. J. (2015). Qualitative research: A guide to design and implementation. San Francisco: Jossey Bass.

Mohamad, A. S., \& Sahad, M. N. (2014). Teori kepimpinan guru dalam pendidikan berasaskan pemikiran al-Ghazali: Satu perbandingan dengan teori kepimpinan pendidikan Barat. Jurnal Akidah \& Pemikiran Islam, Special Issue, 163-196.

Mohamad, N., \& Razak, A.K. (2016). Konsep ta'dib sebagai teras Falsafah Pendidikan Islam. Prosiding Wacana Pendidikan Islam Siri ke 11. ILIM \& Universiti Kebangsaan Malaysia: (pp. 43-49).

Mohamed, S., Jasmi, K. A., \& Zailaini, M. A. (2016). Teacher's good behaviour in teaching and learning the Islamic education. Akademika, 86(2), 31-42.

Mokhtar, S. (2017). Kajian persepsi pelajar terhadap amalan terbaik dalam kalangan guru Pendidikan Islam. Jurnal Pendidikan Guru, 1, 47-60.

Mustafa, Z., \& Salim, H. (2012). Factors affecting students' interest in learning Islamic education. Journal of Education and practice, 3(13), 81-86.

Nashih, U. A. (1989). Pedoman pendidikan anak-anak dalam Islam. Klang: Klang Book Centre.

Nugraha, M. (2017). Konsep ilmu fardu ain dan fardu kifayah dan kepentingan amalannya dalam kurikulum Pendidikan Islam. TAFHIM: IKIM Journal of Islam and the Contemporary World, 10, 103-149. 
INTERNATIONAL JOURNAL OF ACADEMIC RESEARCH IN BUSINESS AND SOCIAL SCIENCES

Vol. 10, No. 3, March, 2020, E-ISSN: 2222-6990 @ 2020 HRMARS

Othman, L. (2014). Penyelidikan kualitatif: Pengenalan kepada teori dan metod. Tanjung Malim Perak: Universiti Pendidikan Sultan Idris.

Othman, Z. (2013). Pembentukan ilmuwan beradab melalui penerapan konsep ta'dib dalam pendidikan: suatu analisis. Journal of Al-Tamaddun, 8(2), 27-35.

Pa, N. A. N. (2014). Memaknai konsep 'ta'dib' dalam pendidikan Islam sekolah rendah dan menengah di Malaysia : Cabaran Tranformasi. In Ibrahim, L.M., Mohamad, S., Jamil, I.A., Kasim, T. S. A. T \& Mamat, A.M. (Eds), Pendidikan Islam Di Malaysia : Cabaran dan Penyelesaian, (pp. 1 -22). Akademi Pengajian Islam, Universiti Malaya.

Ramlie, H. @ H., Hussin, Z. (2017). Ciri-ciri guru pendidikan Islam profesional (GPI) berasaskan riadhah ruhiyyah menurut pandangan al-Ghazali: analisis kandungan bab adab terhadap guru dalam kitab Ihya Ulum al-Din. Al-Hikmah, 9(2), 57-77.

Salleh, S. M., Ahmad, J., Noh, M. A. C., \& Hehsan, A. (2018). Islamic education teacher profile in Malaysia. UMRAN-International Journal of Islamic and Civilizational Studies, 5(1), 80-93.

Sulaiman, A. M. (2014). Peranan guru pendidikan Islam dalam pembentukan akhlak murid dari aspek hubungan guru-murid berasaskan Abu Talib Al-Makki (w. 386H/996M). Doctoral dissertation, University of Malaya.

Tamuri, A. H., \& Ajuhary, M. K. A. (2010). Amalan Pengajaran Guru Pendidikan Islam Berkesan Berteraskan Konsep Mu 'allim. Journal of Islamic and Arabic Education, 2(1), 43-56.

Teh, W. Z. W. (1995). Identiti dan kandungan pendidikan Islam. Kuala Lumpur: Bahagian Hal Ehwal Islam, Jabatan Perdana Menteri. 